\title{
Consumer perceptions of food quality in Malaysia
}

\begin{abstract}
Purpose - This paper was written to gain an understanding of the quality cues that consumers look for in purchasing fresh meat and fresh fruit and vegetables in Malaysia. Through a perceived quality model, this paper identifies the implicit, intrinsic, extrinsic and credence quality cues consumers' use in their decision to purchase fresh meat and fresh fruit and vegetables.
\end{abstract}

Design/methodology/approach - This study utilised the shopping mall intercept survey method. Data were collected from traditional markets and modern retail outlets in the Klang Valley region in Malaysia. A structured questionnaire was designed to measure consumer's perceptions and experiences of food quality when purchasing fresh meat and fresh fruit and vegetables from retail outlets. In this study, univariate data analysis (descriptive analysis, one-way analysis of variance) and exploratory factor analysis were performed to analyse the data sets.

Findings - Freshness (intrinsic cue), was the most frequently cited variable when respondents thought about the quality of both product categories. Other variables included price and cleanliness (extrinsic cues) and Halal (credence cue), which was associated with the quality of fresh meat. Quality was associated with freshness, food safety, nutrition and value. Exploratory factor analysis identified food safety (implicit cue) as the most important construct in the respondents' evaluation of quality for both fresh meat and fresh fruit and vegetables.

Originality/value - There is a paucity of research focusing on consumer's perceptions and experiences of food quality in the purchase of fresh meat and fresh produce in Malaysia. The findings of this research may assist the Malaysian food industry by providing new insights into the consumers' perceptions of food quality.

Keywords: food quality, fresh meat, fruit and vegetables, consumers, Malaysia

Paper type: Research paper 


\section{Introduction}

Malaysia is a country that is highly dependent on food imports. In 2012, Malaysia was self-sufficient in poultry (102\%), and eggs (115\%) (Department of Veterinary Services, n.d.). However, Malaysia is a net importer of rice, fresh vegetables, fish and fish products, dairy products, beef and mutton. In 2011, Malaysia imported food products worth more than RM35 billion ( $\$ 11$ billion USD)(Malaysian Investment Development Authority, 2012).

The livestock industry in Malaysia is divided into two main sectors: (1) the ruminant (beef cattle, dairy cattle, buffaloes, sheep and goats); and (2) the nonruminant sector (poultry and swine). In the period of the Tenth Malaysia Plan (20112015), the livestock industry was expected to report a negative average annual growth rate of $0.1 \%$ per annum (Malaysia, 2010). Conversely, the per capita consumption of beef in Malaysia has increased from $2.4 \mathrm{~kg} /$ year in 1985 to $8.4 \mathrm{~kg} /$ year in 2010 (Consumers Association of Penang, 2011). Despite the increasing demand, the level of self-sufficiency in beef was only $28 \%$ in 2010 . To meet the growing demand for meat in Malaysia, approximately $80 \%$ of the meat is imported from other countries. In 2010, India was the most significant supplier of meat to Malaysia (45\%), followed by Australia (23\%), China (12\%) and New Zealand (11\%)(New Zealand Trade and Enterprise, 2012).

In contrast, the poultry sector is the largest component of the livestock industry. In 2003, poultry accounted for $81 \%$ of the meat produced, followed by pork $(17 \%)$, beef $(2 \%)$ and mutton $(0.1 \%)$ (Ministry of Agriculture, 2005). The poultry industry has not only managed to meet the local demand for chicken, but is also a net exporter of meat and eggs to Singapore and Japan (Mohamed, 2007). In 2003, the level of self-sufficiency for poultry was $104 \%$, but by the end of 2010, the level of self-sufficiency for poultry had increased to $122 \%$. However, Malaysia occasionally imports chicken meat from countries such as China and Thailand to ensure enough supply for the festive seasons such as Eid and the Chinese New Year (Nik Anis, 2009).

The vegetable industry in Malaysia can best be described as small and fragmented (Chong, 2007). The main vegetables cultivated include choy sum, cabbage, cucumber, long bean, chilli and tomatoes (Ministry of Agriculture and AgroBased Industry, 2006). Due to differences in climate, a shortage of suitable land and inadequate skills, Malaysia imports vegetables such as garlic, potatoes, carrots, turnips, onions, cauliflowers, broccoli, ginger and dried chillies from China. Imports from China accounted for $43 \%$ of imports, followed by India (14\%), Thailand (8\%), Australia (6\%), the USA (4\%), the Netherlands (3\%), New Zealand (2\%) and Indonesia (1\%)(Rahim, 2007).

The production of fruit crops in Malaysia is primarily focused on the production of tropical fruits such as durian, banana, pineapples, rambutan, papaya and guava. Temperate fruits such as oranges, apples and table grapes have to be imported into Malaysia. China was the main supplier of imported fruit such as mandarins, apples and preserved fruit to Malaysia (28\%)(Rahim, 2007). Malaysia also imports temperate fruit from the USA (19\%), South Africa (9\%) and Australia (8\%). Recently, the Economic Planning Unit (2011) reported that the import trade for fruit and vegetables into Malaysia was expected to reach RM4,245 million (\$USD 1,327 million). Arshad and Hameed (2007) anticipate that the import value of temperate fruit will increase in the near future due to factors such as an increase in population and household disposal income, changes in consumers' lifestyle, and the inconsistent and unstable supply of tropical fruit. 
As a result of the high dependence on food imports, food quality and safety is emerging as a major issue in Malaysia. Consumers are becoming more demanding in terms of the quality and safety of the food they intend to purchase and consume. This study attempts to gain a greater understanding of how consumers evaluate food quality by identifying and understanding the implicit, intrinsic, extrinsic and credence quality cues for the purchase of fresh meat and fresh fruit and vegetables.

\section{Perceived quality}

For this research study, the term perceived quality was used to describe consumers' quality judgements. These are built on the consumers' perceptions, needs and objectives. The conceptual framework for this study was adapted from Steenkamp (1990), Oude Ophuis and Van Trijp (1995), the Total Food Quality Model (Grunert, Larsen, Madsen and Baadsgaard, 1996), and Peri (2006).

Steenkamp (1990) focused on the theoretical concepts of food quality and value. Value was related to perceived quality through three dimensions: preference, subject-object interaction and the consumption experience. Preference indicates an evaluative judgement, for example, whether the consumer prefers the food or some alternative. Objective interaction occurs through comparison and is influenced by personal and situational contexts. Perceived quality however, ultimately involves the consumption experience, where a product is valued for its purpose after consumption.

Having conceptualised perceived quality along the three dimensions of value, Steenkamp (1990) defined perceived quality as an idiosyncratic value judgement with respect to the fitness for consumption which is based upon the conscious and/or unconscious processing of quality cues in relation to relevant quality attributes within the context of significant personal and situational variables (p.317).

When consumers decide to select a particular food, their preferences are based on several sensory characteristics (taste and texture) and non-sensory characteristics (health, religion, ethics, etc). The non-sensory characteristics are the core values that perceived quality seeks to capture and develop. However, most consumers are largely unaware how the subconscious values and beliefs that they hold influence their food choices.

Oude Ophuis and Van Trijp (1995) have a different approach to defining perceived quality. For them, quality is measurable through certain standards. To define perceived quality, Oude Ophuis and Van Trijp (1995) introduced a quality quadrant, which consisted of four Ps; perception, product, person and place. Perception is the overall judgment of the product characteristics (either visible or invisible), which the consumer can associate with or has experienced when evaluating the product. The other three Ps; product, person and place, represent and relate back to the whole concept of perceived quality. Perceived quality is different, depending on the product category. The personal factor is important, as the whole idea of perceived quality is based on an individual's judgement. Consequently, one person's understanding of perceived quality will be different from another person, since personal preferences and experience levels are likely to differ. Place is associated with situational factors which influence perceived quality.

To understand what perceived quality is, it is important to first identify the quality indicators that surround the concept of perceived quality. Steeenkamp (1990) used the term quality cues, while Oude Ophuis and Van Trijp (1995) used the term perception. 
The Total Food Quality Model (Grunert et al., 2006) was developed as a result of emerging concerns about food quality and safety. This model examined food quality through two different dimensions; a horizontal and a vertical dimension. The horizontal dimension represents the time dimension, which investigates quality perceptions prior to and after purchase. By utilising the three quality attributes (search, experience and credence), consumers are expected to evaluate the quality of food before (quality expectation) and after purchase (quality experience). Consumers' satisfaction or dissatisfaction with the purchase will reflect upon the cues that they have utilised in making the decision to purchase. This means that the consumers' satisfaction or dissatisfaction is determined by the relationship between quality expectations and quality experience.

The vertical dimension involves the means-end approach, which attempts to link product characteristics (quality cues) to the more abstract quality dimensions which are associated with consumer motivations (beliefs, attitudes) and values. When relating food with quality, the concept revolves around four central concepts: sensory characteristics, health, convenience and process characteristics (Grunert, 2005).

Peri (2006) presented a dynamic model of food quality which involved an ongoing process to fulfil consumers changing needs. According to Peri (2006), consumers express their expectations and needs, which are also labelled as 'requirements', which are satisfied by the 'performance' of the product. Unlike Steenkamp (1990) and Grunert (2005) who utilised the concept of attributes, Peri (2006) utilised the concept of 'performance' to capture the importance of quality, which was comprised of the safety, nutritional, sensory, functional, aesthetic, ethical and convenience attributes. 'Performance' was then derived from the 'characteristics' of the product. Peri (2006) further described 'characteristics' as the structural and objective data such as shape, weight, size, structure and composition of the product. The 'characteristics' of the product are obtained through the production process.

Based upon these theories, a conceptual framework to understand how consumers construct perceptions on food quality when purchasing fresh meat and fresh fruit and vegetables in Malaysia was proposed (Figure 1).

Insert Figure 1 about here

\section{Quality cues}

Quality cues are defined as information stimuli that are related to the quality of the product and can be ascertained by the consumer through the senses prior to consumption (Steenkamp, 1990, p.312). Consumers are offered a large number of quality cues in the market. In the consumers' mind, desired cues are gathered and categorised, before making predictions of product quality. How the cues are gathered and categorised are based upon the beliefs and prior knowledge of the product that consumers have experienced.

\section{Implicit cues}

These are derived from consumers' perception that the food they are about to consume is safe (Peri, 2006). Similarly, Keast (2009) found that food safety is an implicit part of food quality, given that safety is what consumers expect when they purchase food. 


\section{Intrinsic cues}

The concept of intrinsic-extrinsic cues was developed by Olson and Jacoby (1972). Intrinsic cues describe the physical attributes of the product, which cannot be changed or manipulated without changing the product itself (Oude Ophuis and Van Trijp, 1995; Grunert, 2005). According to Verbeke et al. (2005), intrinsic cues comprise both search and experience attributes. Consumers may be able to judge search attributes such as appearance, colour, shape, size and structure immediately when doing their food shopping, but, on the other hand, consumers can only evaluate the experience attributes such as taste, tenderness, crunchiness and juiciness after consuming the product. In the buying process, search attributes were found to be significantly more important, while experience attributes were highly valued during consumption (Ragaert et al., 2004).

Freshness is often cited as one of the most influential intrinsic cues impacting on the consumers' decision to purchase fresh meat (Krystallis and Arvanitoyannis, 2006). According to Kennedy et al. (2004), in order to judge freshness, product appearance (which comprises colour and the physical form of the meat) were utilised. Brunso et al. (2002) demonstrated how the visual appearance of meat had a strong association with consumers' quality expectations. For those consumers who shop at the traditional markets in Malaysia, they are often able to touch the meat to determine its freshness before deciding to buy (Chamhuri and Batt, 2009a).

In purchasing fresh vegetables, Toivonen and Brummell (2008) demonstrated that freshness, which is further described by the appearance and the texture of fresh fruit and vegetables, are the main intrinsic cue that is most often associated with good quality. Fruit and vegetables that are not fresh, withered or rotten often indicate poor quality. Von Alvensleben and Meier (1990), state quite emphatically that when purchasing fresh produce, 'consumers buy with their eyes'.

Consumers seek freshness when purchasing fresh meat or fresh produce to maintain good health and to enjoy the taste of the food (Bech et al., 2000).

\section{Extrinsic cues}

According to Oude Ophuis and Van Trijp (1995), extrinsic cues are quality cues that are not related to the physical product, but become an important indicator when comparing between two or more products that are similar in appearance. Price and brand are the best known examples of extrinsic cues. Olson (1977) mentioned that in situations when consumers cannot obtain enough information, price often appears to substitute for quality. Consumers often perceive that products with a higher price are of higher quality (Oude Ophuis and Van Trijp, 1995). However, Zeithaml (1988) suggests that the use of price as an indicator of quality depends on: (1) the availability of other cues; (2) differences in the price for products from the same category; (3) consumers' awareness of the price of the product, and (4) consumers' ability to detect a variation in quality among a group of products.

Extrinsic cues also include store image, which is generally described as the cleanliness of the store (Acebron and Dopico, 2000). Jabbar and Admassu (2009) revealed how cleanliness was measured by the hygiene of staff/butchers and premises. Cleanliness of the equipment to process the meat, washing the meat using clean water and the adoption of hygienic practices can improve the microbiological quality of meat (Rao and Ramesh, 1988).

Similarly, in the purchase of fresh fruit and vegetables, cleanliness was perceived as an important quality indicator for consumers in Central America, where Berdegue et al. (2005) reported that consumers assumed that the fresh fruit and 
vegetables being offered in a clean and tidy supermarket were safer to eat compared to the fresh produce available from a dirty and disorganised traditional market.

\section{Credence cues}

Credence denotes features of the product which are considered important by the consumer, but are not experienced directly in consumption (Becker, 1999). Credence quality cues are associated with a variety of issues including sustainability of agricultural production systems, genetically modified food, animal welfare, farm labour conditions and child labour.

From here, personal values and situational factors will have a strong influence on the consumers' decision to purchase. The beliefs that a consumer holds will determine the level of importance credence quality cues have in influencing the decision to purchase.

Besides placing much importance on purchasing food that is safe and healthy to eat, and produced with environmentally friendly practices, Bonne and Verbeke (2006) demonstrate how religion influences consumers' attitudes towards the food that they purchase. In a Muslim country such as Malaysia, eating food that is Halal is considered important. Generally, Halal means permissible to eat according to Islamic rulings. The definition of Halal includes the slaughtering method, production process, handling method and the safety of meat products (Malaysian Halal Standard MS1500, 2004). Given that the slaughter method cannot be verified by consumers even after consuming the food, they associate this attribute with the place of purchase, where they trust their butcher, who is also Muslim, to deliver Halal meat. According to Bonne and Verbeke (2008), Muslim consumers most trust their family and friends, followed by Islamic butchers, to obtain information about Halal meat.

\section{Research methodology and data analysis procedures}

The survey instrument for this study consisted of two questionnaires which discussed consumer's perceptions and experiences of food quality in purchasing fresh meat and fresh fruit and vegetables. The first few questions in both surveys sought to gather information regarding the store choice behaviour of the respondents, followed by a number of questions with regards to their perceptions of the quality of the respective commodity (fresh meat or fresh produce). Interviews were conducted in a number of both traditional and modern retail markets in the Klang Valley, with one team of researchers administering a meat questionnaire and the other a fresh fruit and vegetable questionnaire.

To capture how respondents evaluate food quality, respondents were asked in an open-ended question about the criteria they considered when thinking about the quality of the fresh meat (or fresh produce) that they buy from their most preferred retail outlet. An open-ended question allowed respondents to freely convey their views with regard to the topic of interest and to ensure that no major variables were excluded from the fixed response question sets. Descriptive analysis was then used to describe the quality criteria respondents most often used in their decision to purchase fresh meat or fresh fruit and vegetables.

According to Wandel and Bugge (1997), the term food quality can be defined in many ways depending on who is performing the evaluation. For consumers, food quality is mainly related to: (1) taste (Grunert et al., 2004); (2) freshness (Wandel and Bugge, 1997); (3) nutritional value (Caswell and Mojduszka, 1996) and (4) food safety (Rico et al., 2007). However, consumers in different societies are often 
interested in the impact that food production has on the environment (Grunert et al., 2004) and the ethical aspects of food production (Caswel, 2000).

As quality revolves around these characteristics, the next group of questions were designed to measure the respondents' level of agreement/disagreement with a number of statements that described the quality concept. A six point Likert scale was utilised for this group of questions, where 1 was "I disagree a lot" and 6 was "I agree a lot". Two additional statements for the fresh meat survey were introduced to evaluate the influence that Halal (Bonne and Verbeke, 2006) and animal welfare (Wandel and Bugge, 1997) had on their perceptions of quality. This group of questions were then analysed using a one-way ANOVA to identify any significant differences in the rank order of the 18 quality statements.

The reality is however, that respondents rarely use all 18 criteria, for food is often considered to be a low involvement purchase (Beharrell and Denison, 1995). Exploratory factor analysis, with varimax rotation and Kaiser normalisation was applied to group the variables into a smaller, more manageable set of variables, while retaining as much of the information as possible (Field, 2009).

At the end of the questionnaire, socio-demographic information such as gender, age, ethnicity and occupation were collected. In all, the sample for the study consisted of 544 respondents, where 260 respondents participated in the fresh meat survey and 284 respondents participated in the fresh fruit and vegetables survey.

\section{Results}

Respondents

The majority of respondents in this study were females, aged between 26 and 44 years old, most of who were married and were of Malay descent. Most respondents from both surveys possessed at least an undergraduate degree. The majority of respondents were employed either within the private sector, the government sector or owned their own business. In terms of income, most respondents earned between RM2,000 to RM4,000 per month (approximately between USD650 to USD1,300). The United Nations' International Labour Organisation (ILO) reported that the average monthly salary in Malaysia was about USD961 per month (Average Monthly Salary for 72 Countries in the World, 2012)

\section{Fresh meat survey}

In thinking about the quality criteria respondents most often used in their decision to purchase fresh meat, irrespective of the retail store, freshness (83\%) was the most frequently cited variable (Table I).

\section{Insert Table I about here}

Other quality variables most frequently cited by respondents included Halal $(58 \%)$, cleanliness $(44 \%)$ and price $(35 \%)$. Quality was also associated with a range of variables which described the physical appearance of the meat such as colour $(18 \%)$, texture (16\%) and smell $(15 \%)$. Quality was also perceived to mean safe to eat (14\%) and to be free from any chemicals and growth promotants (11\%).

Respondents were then asked to indicate the extent to which they agreed with 18 quality statements on a scale of 1 to 6 , where 1 was "I disagree a lot" and 6 was "I agree a lot". Eleven variables were afforded the highest measure of agreement (Table II). 
For the majority of respondents, good quality meant that the meat was fresh, safe to eat, and free from chemical residues, pests and diseases, antibiotics and growth promotants. Good quality meat was nutritious, tasted good and was highly correlated with value (that is, respondents would not be disappointed after consuming the meat, they were able to utilise most of the product, and thus the purchase represented good value for money). While Halal was also perceived to be a reliable indicator of good quality, the high standard deviation indicated considerable variance in the responses suggesting that the need for the meat to be Halal was not important for all respondents.

That variable which was the least often associated with good quality was a high price, suggesting that in the purchase of fresh meat, there was little association between quality and price.

Exploratory factor analysis revealed three factors which collectively explained $75 \%$ of the variance (Table III).

Insert Table III about here

Factor One, with an Eigenvalue of 3.67, captured three items that accounted for $28 \%$ of the variance. The Cronbach's alpha for this factor was 0.82 . Collectively, these three items described "meat production" which was comprised of the extent to which respondents were concerned about the environment, farmers' welfare and animal welfare. This was the second most highly rated factor respondents considered when thinking about the quality of fresh meat.

Factor Two, with an Eigenvalue of 1.26 also had three items. It accounted for $26 \%$ of the variance. The Cronbach's alpha for this factor was 0.77 . Items in Factor Two described the utility of the meat product: looks attractive, attractively packaged and long shelf life. Despite the benefits the product may have to offer, this was the least highly rated factor in the respondents' mind when considering the quality of fresh meat.

Factor Three, with an Eigenvalue of 1.0, captured two items that accounted for $21 \%$ of the variance. The Cronbach's alpha for this factor was 0.76 . This factor was labelled as "safe" for it captured the respondents concerns with regards to food safety and freshness. Not unexpectedly, Factor Three was the most highly rated factor in the respondents' evaluation of meat quality.

\section{Fresh fruit and vegetables survey}

In thinking about the quality criteria respondents most often used in their decision to purchase fresh fruit and vegetables, freshness (93\%) was the most frequently cited variable (Table IV).

Insert Table IV about here

Price (41\%) was the second most frequently cited variable, followed by cleanliness (31\%). Quality of fresh produce were also associated with such variables as nutrition $(20 \%)$, freedom from chemicals $(17 \%)$, safe to eat $(15 \%)$, and other variables which described the physical attributes of the product such as texture (15\%), 
colour $(12 \%)$, and size/shape $(11 \%)$. Several respondents also mentioned quality $(12 \%)$, taste $(11 \%)$ and nicely packaged $(10 \%)$ as variables which were indicative of the quality of fresh fruit and vegetables.

Halal (4\%) and smell (4\%) were among the most infrequently cited variables when respondents thought about the quality of fresh fruit and vegetables.

When asked to indicate the extent to which they agreed with sixteen quality statements associated with purchasing fresh fruit and vegetables from a retail store, seven variables were identified by respondents as having the highest level of agreement (Table V).

\section{Insert Table $\mathrm{V}$ about here}

For most respondents, good quality meant that the fruit and vegetables purchased were fresh, safe to eat, free from chemical residues, free from pests and diseases, nutritious, were good value for money and the respondent was unlikely to be disappointed with the purchase after consuming the product. Attractive packaging and a high price were the two variables that were least often associated with quality.

Exploratory factor analysis revealed three factors which collectively explained $69 \%$ of the variance (Table VI).

\section{Insert Table VI about here}

Factor One, with an Eigenvalue of 3.84 captured four items and accounted for $27 \%$ of the variance. Items in Factor One described the "food safety issues" such as freedom from chemical residues, freedom from pests and diseases, safe to eat and nutritious. The Cronbach's alpha for this factor was 0.80 . Not unexpectedly, this factor was the most influential in determining the respondents' perceptions of the quality of the fresh fruit and vegetables offered for sale.

Factor Two captured three items and had an Eigenvalue of 1.29. These three items described the "value for money" of the fresh produce purchased. The Cronbach's alpha for this factor was 0.72 and it explained $23 \%$ of the variance. Similar to Factor One, this factor was first equal in determining the respondents' perceptions of the quality of the fresh fruit and vegetables they intended to purchase.

Factor Three included two items that collectively captured the "utility of packaging". It accounted for $19 \%$ of the variance. The Cronbach's alpha for this factor was 0.77. Regardless of the benefits of packaging, this factor was the least influential when respondents considered the quality of the fresh fruit and vegetables available in a retail store.

\section{Discussion}

When thinking about the quality of fresh meat and fresh fruit and vegetables, freshness, which is an intrinsic cue, was the most frequently cited variable respondents considered (Table VII).

Insert Table VII about here

Freshness, which can be further described as the physical appearance of the meat such as flesh colour, was among the variables most frequently cited by respondents as leading them to believe that the meat was of superior quality. This 
finding concurs with Becker (1999), Bonne and Verbeke (2006), and Krystallis and Arvanitoyannis (2006) who found that consumers described the quality of beef by judging its freshness, leanness and bright red colour. Kennedy et al. (2004) mentioned that consumers rely entirely on visual cues such as freshness as one of the primary indicators of poultry meat quality. Kennedy et al. (2004) then further elaborated that in purchasing chicken from a retail store, consumers utilised the intrinsic quality cues (freshness, appearance, colour) to reflect other functional attributes (taste and healthfulness). For the purchase of fresh beef, Carpenter et al. (2001) agreed that the colour of the meat, particularly bright red, positively affected consumers' likelihood of purchasing the product.

Given that the characteristics of fresh meat and fresh fruit and vegetables are different from each other, it was no surprise to find that the attributes which defined freshness for both products were also very different. Even in the fresh produce category, the indicators of freshness varied across the different types of fruit and vegetables. In the case of potatoes and apples, the freshness of the produce was described by the skin colour, freedom from blemishes and bruises, texture and firmness. For spinach, freshness was visually assessed by the colour, freedom from wilting, and the appearance of the leaves.

Beside freshness, the findings also revealed that Halal (a credence cue) was frequently cited when respondents thought about the quality of the fresh meat they intended to purchase from a retail store. This finding concurs with Riaz and Chaudry (2004) who mentioned that Halal was perceived to offer the highest standard of quality for Muslim and for many non-Muslim consumers. However, Halal was not a consideration in determining the quality of fresh fruit and vegetables, for fresh fruit and vegetables are naturally Halal.

When comparing between the indicators of quality, price (an extrinsic cue) was the second most frequently cited variable for fresh fruit and vegetables, whereas price was the fourth most frequently cited variable for fresh meat. This does not mean that consumers care less about the price when thinking about meat, for as indicated by Becker (1999), consumers do not always assume that a higher price will lead to superior quality. Glitsch (2000) revealed that price was regarded as being the least helpful for assessing the quality of meat.

For fresh fruit and vegetables, price was the second most frequently cited variable used by respondents as an indicator of quality. As Malaysia imports most of its fresh produce from China (Calvin et al., 2006; Rahim, 2007), the fresh fruit and vegetables imported from Australia, New Zealand and the USA, are not only more expensive than those imported from China, but are generally of better quality (Chamhuri and Batt, 2009b).

Consumers prefer to purchase from retail stores that provide high quality fresh meat and fresh produce in a clean environment (extrinsic cue). However, which retail store offers the best quality fresh meat and fresh produce is based on the individual's perceptions and judgements of the product. Lui (2008) suggests that traditional markets and supermarkets provide a polarised physical experience for consumers such as "dirty" opposed to "clean", or an "unpleasant" versus a "comfortable" environment. If the quality of fresh meat and fresh produce was determined solely on the cleanliness of the store, supermarkets and hypermarkets would have an advantage over the traditional markets. As a result of the unhygienic condition in most traditional retail outlets, consumers who were concerned about cleanliness chose to purchase their fresh food from a modern retail outlet. 
The quality of both fresh meat and fresh fruit and vegetables revolved around freshness, food safety (safe to eat, free from chemical residues, free from pests and disease), nutrition and value (will not be disappointed when eating the product and good value for money)(Table VIII).

Insert Table VIII about here

Wandel and Bugge (1997) similarly considered the multi-faceted nature of food quality to include such variables as taste, freshness, appearance, nutritional value and food safety. Grunert et al. (2004) considered food quality to include sensory attributes, food safety, health and nutritional value.

Respondents also considered several additional criteria which were perceived to influence the quality of fresh meat; Halal guaranteed, free from antibiotics/growth promotants, good taste and the ability to use most of the product purchased. This would suggest that respondents believed that the purchase of fresh meat required more thought and effort, compared to the purchase of fresh fruit and vegetables. As the price of fresh meat is generally more expensive per $\mathrm{kg}$ than fresh fruit and vegetables, consumers' involvement in the purchase of fresh meat will be higher. Consumers are therefore expected to gather more information and to be more involved in the decision to purchase to avoid making the wrong choice (Verbeke et al., 2005).

Exploratory factor analysis identified three constructs which collectively captured the respondents' perceptions of the quality of both fresh meat and fresh fruit and vegetables (Table IX).

\section{Insert Table IX about here}

Similar results have indicated that the quality of fresh food was most often related to the safety of the product. For fresh meat, safe was determined by the freshness of the product. In Hoffmann (2000), food safety was assessed by the country-of-origin and the freshness of the meat. Cowan (1998), and Henson and Northern (2000) reported that freshness was the main cue in determining the safety of meat in six European countries. For fresh fruit and vegetables, safe indicates that the product is free from chemical residues, pests and diseases, and is also nutritious. The presence of chemical residues has become a major health concern for consumers in their purchase of fresh fruit and vegetables (Henneberry et al., 1999). Given that Malaysia is a major importer of many types of fresh produce from China, India, Indonesia and Thailand, as reported by Calvin et al. (2006), Chinese farmers are among the world's highest users of chemical fertilisers and pesticides, many of which are banned in the United States.

Respondents also indicated that the safety of the fresh fruit and vegetables they purchased was determined by the absence of any pests and diseases. Molnar (1995) suggested that the presence of pathogens and parasites in food can be hazardous. To support the findings by Molnar (1995), Torjusen et al. (2001) revealed that food such as organics, which has not been genetically modified and does not contain any harmful substances, was considered among the most important criteria after freshness and taste. 
An additional construct (value for money) was afforded similar measures of agreement as food safety in indicating the quality of the fresh fruit and vegetables purchased by respondents. Value for money was further described by three variables; (1) will not be disappointed when eating the food (what consumers want in a product), (2) good value for money (cost), and (3) the ability to use most of the product (no wastage). Similarly, Campbell et al. (2009) demonstrated that consumers were concerned about the value (reducing the wastage and money spent) of the fruit they had purchased. As fresh fruit deteriorates, many consumers do not discard undesirable fruit. Among the approaches to maximise the value of the fruit purchased, consumers may: (1) remove the "bad" bits and consume the reminder of the fruit, (2) find an alternative use for the fruit such as baking and stewing, or (3) increase the frequency of shopping to optimise the freshness of the fruit.

Sabbe et al. (2009) explained value for money in terms of price, which has raised two different arguments. Firstly, there are consumers who are prepared to pay a premium price, given that the fruit was bought for the taste and indulging character. Nevertheless, Sabbe et al. (2009) also found that consumers do not want to pay a high price and to be disappointed (expectations are often not confirmed). Both Campbell et al. (2009) and Sabbe et al. (2009) agreed that the opportunity to taste the fruit prior to purchase will be most influential in the consumers' decision to purchase.

In comparison to fresh meat, although previous discussions have indicated that consumers emphasised value more in making their purchase to purchase fresh meat, value for money did not appear among the factors influencing the quality of fresh meat. Respondents ranked meat production (production will not cause danger to farmers, environment and animals) as the second most highly rated factor. According to Caswell and Mojduszka (1996), food quality is determined by a number of characteristics, including food safety, nutrition and value, as well as the production process (animal welfare and environmental impact). Over the last 10 to 15 years, consumers in most European countries have become interested in the way food products are produced (Grunert et al., 2004). According to Wandel and Bugge (1997), phrases such as environmentally sound production and animal welfare are beginning to be included in the discussions of food quality. As a result of this, it was anticipated that consumers will begin to choose between competing products on the basis of production processes or some other ethical considerations that determine if the food is of better quality. In parallel, researchers question whether consumers will be willing to pay an additional price premium to secure these additional attributes.

\section{Conclusions and implications}

The findings indicated that the variables most frequently cited by respondents when they thought about the quality of fresh meat and fresh fruit and vegetables consisted of intrinsic, extrinsic and credence cues. Freshness, which describes an intrinsic cue, was the most frequently cited variable when respondents thought about the quality of both fresh food products. When consumers choose a piece of meat or a type of fruit or vegetables from a retail outlet, they would normally select the ones that are fresh and look the best to indicate that the food is of good quality.

Other variables cited (price and cleanliness) by respondents to describe the quality of fresh meat and fresh fruit and vegetables represented extrinsic cues. Given that fresh meat and fresh fruit and vegetables are generic food products, respondents may need to utilise and compare the price and cleanliness of the retail outlet to determine the quality of the fresh food. 
This study provides valuable information to several groups. Firstly, this research provides valuable information for marketers to understand the behaviour of Malaysian consumers in determining the quality of fresh meat and fresh fruit and vegetables from retail outlets. A consistent pattern was found where respondents emphasised similar criteria (freshness, cleanliness, price and Halal) in their decision to purchase fresh food that they believed to be high quality. Although much of the literature has focused on how to produce quality food, to improve quality in the food industry, more attention must be directed towards gaining a greater understanding as to how consumers perceive quality. Ultimately, consumers are the ones who decide what quality they want and expect in the food that they consume.

Furthermore, Malaysians have emphasised the importance of food safety (implicit cue) when purchasing quality fresh meat and fresh fruit and vegetables from different retail outlets. Traditional retailers are anticipated to change the way they currently operate if they are to become more competitive. Webster (2004) added that due to food safety concerns in the purchase of fresh meat, consumers in Asia, particularly the younger consumers, have strong preferences towards purchasing meat that is chilled or frozen. As a result of this, retailers in the traditional markets are shifting towards more modern systems of selling meat to consumers.

The findings of this paper may also assist the government in developing new strategies to further enhance the Malaysian food industry in conjunction with developing agriculture as the engine of growth in the Malaysian economy. Given that Malaysia relies heavily on imported food, the attributes utilised by consumers when purchasing fresh food of high quality could provide the basis for government to redevelop the livestock industry, and the fresh fruit and vegetable industry. As Malaysia still relies on imported food, the importance of providing competitively priced, good quality, Halal and safe food should not be neglected. 


\section{References}

Abbott, A., and Pearson, H. (2004), "Fear of human pandemic grows as bird flu sweeps through Asia", available at www.nature.com/nature (accessed 17 March 2010).

Acebron, L.B., and Dopico, D.C. (2000), "The importance of intrinsic and extrinsic cues to expected and experienced quality: An empirical application for beef", Food Quality and Preference, Vol. 11, pp. 229-238.

Anklam, E., and Battaglia, R. (2001), "Food analysis and consumer protection", Trends in Food Science and Technology, Vol. 12 No. 5-6, pp. 197-202.

Arshad, F.M. (2007), "Agricultural development path in Malaysia", in Arshad, F.M., Abdullah, N.R., Kaur, B., and Abdullah, A.M. (Eds.), 50 Years of Malaysian Agriculture: Transformational Issues and Challenges, Universiti Putra Malaysia Press, Serdang, pp. 3-46.

Arshad, F.M., and Hameed, A.A. (2007), "The Malaysian fruits industry in half a century: Realities and prospects", in Arshad, F.M., Abdullah, N.R., Kaur, B., and Abdullah, A.M. (Eds.), 50 Years of Malaysian Agriculture:

Transformational Issues and Challenges, Universiti Putra Malaysia Press, Serdang, pp. 309-336.

Average Monthly Salary for 72 Countries in the World (2012). Available at: http://1million-dollar-blog.com/average-monthly-salary-for-72-countries-in-the-world/ (accessed 10 December 2013).

Batt, P.J., and Sadler, C. (1999), "Labels on apples; Winners and losers", in J.Cadeaux and M. Uncles (Eds), Marketing in the third millennium: Proceedings of the Australia New Zealand Marketing Academy. Sydney: University of New South Wales [CD]

Bech, A.C., Juhl, H.J., Hansen, M., Marthens, M., and Anderson, L. (2000), "Quality of peas modelled by a structural equation system", Food Quality and Preference, Vol. 11, pp. 275-281.

Becker, T. (1999), "The economics of food quality standards" presented at Second Interdisciplinary Workshop on Standardisation Research, University of the Federal Armed Forces Hamburg.

Beharrell, B., and Denison, T.J. (1995). "Involvement in a routine food shopping context”, British Food Journal, Vol. 97 No. 4, pp. 24-29.

Berdegue, J.A., Balsevich, F., Flores, L., and Reardon, T. (2005), “Central American supermarkets' private standards of quality and safety in procurement of fresh fruits and vegetables", Food Policy, Vol. 30 No. 3, pp. 254-269. 
Bernues, A., Olaizola, A., and Corcoran, K. (2003), "Extrinsic attributes of red meat as indicators of quality in Europe: an application for market segmentation", Family Quality and Preference, Vol. 14, pp. 265-276.

Bonne, K. and Verbeke, W. (2006), “Muslim consumer's motivations towards meat consumption in Belgium: qualitative exploratory insights from means-end chain analysis", Anthropology of Food, Retrieved from http://aof.revues.rg/index $90 . h t m l$

Bonne, K. and Verbeke, W. (2008), "Muslim consumer trust in Halal meat status and control in Belgium”, Meat Science, Vol. 79 No.1, pp. 113-123.

Brunso, K., Fjord, T.A., and Grunert, K.G. (2002), “Consumers' food choice and quality perception", Aarhus: Aarhus School of Business, MAPP - Centre for Research on Customer Relations in the Food Sector.

Calvin, L., Gale, F., Hu, D., and Lohmar, B. (2006), "Food safety improvements underway in China", Amber Waves, November, pp. 16-21.

Campbell. R.L., Smith, B.G., Jaeger, S. R., and Harker, F.R. (2009), "Deterioration and disposal of fruit in the home: Consumer interviews and fruit quality assessments", Journal of the Science of Food and Agriculture, Vol. 89 No. 1, pp. 24-32.

Carpenter, C.E., Cornforth, D.P., and Whittier, D. (2001), “Consumer preferences for beef colour and packaging did not affect eating satisfaction", Meat Science, Vol. 57 No. 4, pp. 359-363.

Caswell, J.A. and Mojduszka, E.M. (1996), "Using informational labelling to influence the market for quality in food products", American Journal of Agricultural Econonomics, Vol. 78 No. 5, pp. 1248-1253.

Caswell, J.A. (2000), "Valuing the benefits and costs of improved food safety and nutrition", Australian Journal of Agricultural and Resource Economics, Vol. 42 No. 4, pp. 409-424.

Chamhuri, N. (2011), “Consumers' Perceptions and Experiences of Food Quality in Purchasing Fresh Food from Retail Outlets in Malaysia", PhD thesis, Curtin University.

Chamhuri, N. and Batt, P.J. (2009a), "Factors influencing consumers' choice of retail stores for fresh meat in Malaysia", Paper presented at the $19^{\text {th }}$ Annual World Food and Agribusiness Forum and Symposium, Budapest, Hungary, 20-23 ${ }^{\text {rd }}$ June 2009.

Chamhuri, N. and Batt, P.J. (2009b), "Consumer choice of retail outlet: Focus group interviews in Malaysia”, Acta Horticulturae, Vol. 831, pp. 237-246.

Chong, E.F. (2007), "The Malaysian vegetable industry", in Arshad, F.M., Abdullah, N.R., Kaur, B., and Abdullah, A.M. (Eds.), 50 Years of Malaysian Agriculture: 
Transformational Issues and Challenges, Universiti Putra Malaysia Press, Serdang, pp. 337-358.

Consumers Association of Penang, (2011), "Malaysia should support and adopt sustainable indigenous knowledge and practices for livestock husbandry" available at: http://www.consumer.org.my/index.php/development/naturalfarming/473-malaysia-should-support-and-adopt-sustainable-indigenousknowledge-and-practices-for-livestock-husbandry (accessed 15 October 2012).

Cowan, C. (1998), "Irish and European consumer views on food safety", Journal of Food Safety, Vol. 18 No. 4, pp. 275-295.

Department of Standards Malaysia (2004), "Halal food-Production, preparation, handling and storage - General guidelines (first revision), MS 1500, SIRIM Berhad, Malaysia.

Department of Veterinary Services (n.d.), "Malaysia: Self-Sufficiency in Livestock Products (\%) 2003 - 2012" available at:http://www.dvs.gov.my/documents/10157/77c2c28b-1263-4118-b3ed90581731f668 (accessed 10 December 2013).

Egan, A.F., Ferguson, D.M., and Thompson, J.M. (2001), "Consumer sensory requirements for beef and their implications for the Australian beef industry", Australian Journal of Experimental Agriculture, Vol. 41 No. 7, pp. 855-859.

External Trade Report (2011). The official website of the Economic Planning Unit. Accessed May 1, 2012 from http://www.epu.gov.my

Glitsch, K. (2000), "Consumer perceptions of fresh meat quality: Cross-national comparison”, British Food Journal, Vol. 102 No. 3, pp. 177-194.

Goldman, A., Krider, R., and Ramaswami, S. (1999), "The persistent competitive advantage of traditional food retailers in Asia: Wet market's continued dominance in Hong Kong", Journal of Macromarketing, Vol. 19 No. 2, pp. 126-139.

Grunert, K.G. (2005), "Food quality and safety: Consumer perception and demand", European Review of Agricultural Economics, Vol. 32 No. 3, pp. 369-391.

Grunert, K.G., Larsen, H.H., Madsen, T.K., and Baadsgaard, A. (1996), "Market orientation in food and agriculture", Norwell, Massachusetts, Kluwer Academic.

Grunert, K.G., Bredahl, L., and Brunso, K. (2004), “Consumer perception of meat quality and implications for product development in the meat sector $-\mathrm{a}$ review", Meat Science, Vol. 66, pp. 259-272.

Henson, S. and Northern, J. (2000), "Consumer assessment of the safety of beef at the point of purchase: A pan-European study", Journal of Agricultural, Vol. 51 No. 1, pp. 90-105. 
Hoffmann, R. (2000), "Country of origin - A consumer perception perspective of fresh meat", British Food Journal, Vol. 102 No. 3, pp. 211-229.

Holbrook, M.B., and Corfman, K.P. (1983), "Quality and other types of value in the consumption experience: Phaedrus Rides Again”, working paper, Columbia University, New York.

Hsu, J.L., and Chang, W.H. (2002), "Market segmentation of fresh meat shoppers in Taiwan", International Review of Retail, Distribution and Consumer Research, Vol. 12 No. 4, pp. 423-436.

Jabbar, M.A., and Admassu, S.A. (2009), "Assessing consumer preferences for quality and safety attributes of food in the absence of official standards: The case of beef in Ethiopia", paper presented at the International Association of Agricultural Economists conference, Beijing, China, 16-22 August 2009.

Jaeger, S.R., Andani, Z., Wakeling, I.N., and MacFie, H.J. (1998), "Consumer preferences for fresh and aged apples: a cross-cultural comparison”, Food Quality and Preference, Vol. 9 No. 5, pp. 355-366.

Keast, R.S.J. (2009), "Food quality perception", in Enrique, O.R. (Ed.), Processing effects on safety and quality of foods, Boca Raton, Fla, CRC Press, pp. 67-83.

Kennedy, O.B., Stewart-Knox, B.J., Mitchell, P.C., and Thurnham, D.I. (2004), "Consumer perceptions of poultry meat: A qualitative analysis", Nutrition and Food Science, Vol. 34 No. 3, pp. 122-129.

Krystallis, A., and Arvanitoyannis, I.S. (2006), "Investigating the concept of meat quality from the consumers' perspective: The case of Greece", Meat Science, Vol. 72 No. 1, pp. 164-176.

Lui, S. (2008), "An ethnographic comparison of wet markets and supermarkets in Hong Kong”, The Hong Kong Anthropologist, Vol. 2, pp. 1-52.

Malaysia (2006), Ninth Malaysia Plan 2006 -2010, Government Printers, Kuala Lumpur.

Malaysia (2010), Tenth Malaysia Plan 2011 -2015, Government Printers, Kuala Lumpur.

Consumers Association of Penang, (2011), "Malaysia should support and adopt sustainable indigenous knowledge and practices for livestock husbandry" available at: http://www.consumer.org.my/index.php/development/naturalfarming/473-malaysia-should-support-and-adopt-sustainable-indigenousknowledge-and-practices-for-livestock-husbandry (accessed 15 October 2012).

Malaysia Investment Development Authority, (2012), "Industries in Malaysia: Food Industry" available at: http://www.mida.gov.my/env3/index.php?page=foodindustries (accessed 10 December 2013). 
Molnar, P.J. (1995), “A model for overall description of food quality”, Food Quality and Preference, Vol. 6 No. 3, pp. 185-190.

McCarthy, M., and O'Reilly, S. (1999), "Beef purchase behaviour: Consumer use of quality cues and risk reduction strategies - findings from focus group discussions", Discussion Paper Series, Department of Food Business and Development, University College Cork, Ireland.

McEachern, M.G., and Schroder, M.J. (2002), "The role of livestock production ethics consumer values towards meat", Journal of Agricultural and Environmental Ethics, Vol. 15 No. 2, pp. 221-237.

McIntyre, I. (2008), "Malaysia bans Thai chicken imports after bird flu in Sokhotai", The Star, 15 November.

Merican, Z. (1995). Halal food industry in Malaysia - Opportunities and constraints. Conference on Halal Foods: Meeting market needs.

Ministry of Agriculture Malaysia (2005), Livestock Statistics, DVS, Kuala Lumpur.

Ministry of Agriculture and Agro-based Industry Malaysia (2006), Agricultural Statistical Handbook 2006, Kuala Lumpur.

Mohamed, Z.A. (2007), “The livestock industry”, in Arshad, F.M., Abdullah, N.R., Kaur, B., and Abdullah, A.M. (Eds.), 50 Years of Malaysian Agriculture: Transformational Issues and Challenges, Universiti Putra Malaysia Press, Serdang, pp. 553-584.

Moye, L.N. (2000), "Influence of shopping orientation, selected environmental dimensions with apparel shopping scenarios and attitude on store patronage for female consumers", $\mathrm{PhD}$ thesis, Virginia Polytechnic Institute and State University, Blackburg.

New Zealand Trade and Enterprise (2012), Export Guide: Food and Beverage in Malaysia, New Zealand.

Nik Anis, M. (2009), “Temporary stop to chicken from China”, The Star, 21 January.

Olson, J.C. (1977), "Price as an informational cue: Effects in product evaluation", in Woodside, A.G., Sheth, J.N., and Bennet, P.D. (Eds), Consumer and industrial buying behaviour, New York: North Holland Publishing Company, pp. $267-286$.

Olson, J.C., and Jacoby, J. (1972). Cues utilisation in the quality perception process in Proceedings of the Third Annual Conference of the Association of Consumer Research, ed. M.Venkatesan (pp. 67-79). Association for Consumer Research, Iowa City. 
Oude Ophuis, P.A.M., and van Trijp, H.C.M. (1995), "Perceived quality: A market driven and consumer oriented approach", Food Quality and Preference, Vol. 6 No.3, pp. 177-183.

Pearson, D. (2005), "Marketing fresh fruits and vegetables: Exploration of individual product characteristics and their relationship to buyer's attention to price", Australian Agribusiness Review, Vol. 13, pp. 1-13.

Peri, C. (2006), "The universe of food quality", Food Quality and Preference, Vol. 17 No. 1-2, pp. 3-8.

Ragaert, P., Verbeke, W., Devlieghere, F., and Debevere, J. (2004), “Consumer perception and choice of minimally processed vegetables and packaged fruit", Food Quality and Preference, Vol. 15 No. 3, pp. 259-270.

Rahim, H.A. (2007), "Marketing of food products", in Arshad, F.M., Abdullah, N.R., Kaur, B., and Abdullah, A.M. (Eds.), 50 Years of Malaysian Agriculture: Transformational Issues and Challenges, Universiti Putra Malaysia Press, Serdang, pp. 669-700.

Rao, D.N., and Ramesh, B.S. (1988), "Microbial profiles of minced meat", Meat Science, Vol. 23, pp. 279-291.

Resurreccion, A.V. (2003), "Sensory aspects of consumer choices for meat and meat products”, Meat Science, Vol. 66 No. 1, pp. 11-20.

Riaz, M.N. (1996), “Hailing Halal”, Prepared Foods, Vol. 165 No. 12, pp. 53-54.

Rico, D., Martin-Diana, A.B., Barat, J.M., and Barry-Ryan, C. (2007), "Extending and measuring the quality of fresh-cut fruit and vegetables: a review", Trends in Food Science and Technology, Vol. 18 No. 7, pp. 373-386.

Steenkamp, J-B.E.M. (1990), "Conceptual model of the quality perception process", Journal of Business Research, Vol. 21 No. 4, pp. 309-333.

"The official website of Malaysian Industrial Development Authority" (n.d.), available at http://www.mida.gov.my/en v2/ (accessed 27 October 2010).

Toivonen, P.M., and Brummell, D.A. (2008), "Biochemical bases of appearance and texture changes in fresh-cut fruit and vegetables", Postharvest Biology and Technology, Vol. 48 No. 1, pp. 1-14.

Torjusen, H., Leiblein, G., Wandel, M., and Francis, C.A. (2001), "Food system orientation and quality perception among consumers and producers of organic food in Hedmark County, Norway", Food Quality and Preference, Vol. 12 No. 3, pp. 207-216.

Verbeke, W., Demey, V., Bosmans, W., and Viaene, J. (2005), "Consumer versus producer expectations and motivations related to 'superior' quality meat", Journal of Food Products Marketing, Vol. 11 No.3, pp. 27-41. 
Vinning, G., and Tshering, C. (2005), "Recent trends and future prospects of fruit and vegetable marketing in Asia and the Pacific - an overview", paper presented at the Seminar on Improvement of Agricultural Marketing Systems for Enhancing International Competitiveness, Asian Productivity Organisation, Islamabad, Pakistan 7-12 February.

Von Alvensleben, R., and Meier, T. (1990), "The influence of origin and variety on consumer perception”, Acta Horticulturae, Vol. 259, pp. 151-161.

Vos, E. (2000), "EU food safety regulation in the aftermath of the BSE crisis", Journal of Consumer Policy, Vol. 23, pp. 227-255.

Wandel, M., and Bugge, A. (1997), "Environmental concern in consumer evaluation of food quality", Food Quality and Preference, Vol. 8 No. 1, pp. 19-26.

Warriss, P.D. (2000), "Meat science: An introductory text", Wallingford, Oxon: CABI Publishing.

Webster, R.G. (2004), "Wet markets - a continuing source of severe acute respiratory syndrome and influenza", Lancet, Vol. 363, pp. 234-236.

Wilcock, A., Pun, M., Khanona, J., and Aung, M. (2004), "Consumer attitudes, knowledge and behaviour: A review of food safety issues", Trends in Food Science and Technology, Vol. 15 No. 2, pp. 56-66.

Zeithaml, V.E. (1988), "Consumer perceptions of price, quality, and value: A MeansEnd Model and synthesis of evidence", Journal of Marketing, Vol. 52 No.3, pp. 2-22. 